\title{
MASTER
}

MHSMP-75-40F

\section{TATB PBX FORMULATIONS}

\author{
H. D. Johnson \\ A. G. Osborn \\ T. L. Stallings
}

DEVELOPMENT DIVISION

JULY - SEPTEMBER 1975

Normal Process Development Endeavor No. 106

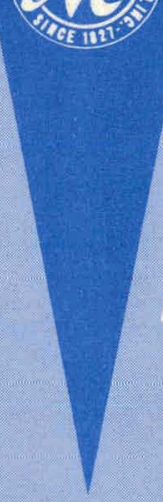

\section{Ollowion a Oariear Plans \\ P. $0.80 \times 647$ \\ Amaritio, taxas 79177 \\ $806-335-1581$}

operated for the

ENERCY RESEARCH AND DEVELOPMENT ADMUNISTRATION under

U. S. GOVERNMENT Contract DA 11.173 AMC.487(A) 


\section{DISCLAIMER}

This report was prepared as an account of work sponsored by an agency of the United States Government. Neither the United States Government nor any agency Thereof, nor any of their employees, makes any warranty, express or implied, or assumes any legal liability or responsibility for the accuracy, completeness, or usefulness of any information, apparatus, product, or process disclosed, or represents that its use would not infringe privately owned rights. Reference herein to any specific commercial product, process, or service by trade name, trademark, manufacturer, or otherwise does not necessarily constitute or imply its endorsement, recommendation, or favoring by the United States Government or any agency thereof. The views and opinions of authors expressed herein do not necessarily state or reflect those of the United States Government or any agency thereof. 


\section{DISCLAIMER}

Portions of this document may be illegible in electronic image products. Images are produced from the best available original document. 


\section{NOTICE}

This report was prepared as an account of work sponsored by the United States Government. Neither the United States nor the United States Energy Research and Development Administration, nor their employees, nor any of their contractors, subcontractors, or their employees, makes any warranty, express or implied, or assumes any legal liability or responsibility for the accuracy, completeness or usefulness of any information, apparatus, product or process disclosed, or represents that its use would not infringe privately-owned rights. 


\title{
TATB PBX FORMULATIONS
}

\author{
H. D. Johnson
}

A:" G!" Osborn

T. L. Stallings

DEVELOPMENT PIVISION

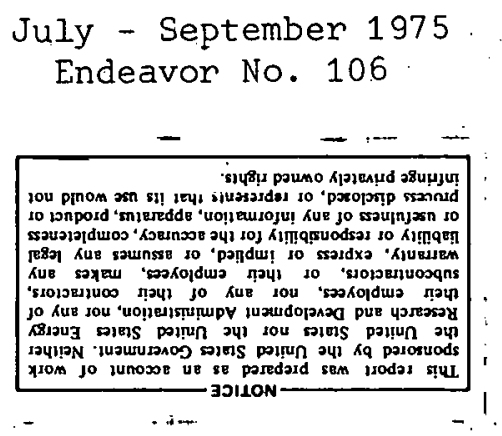

F-1 


\section{ABSTRACT}

A series of six processing parameter studies were conducted in the 30 litre reactor. Batch concentration emerged as the most important single variable affecting physical properties other than granule size which has previously been reported.

\section{INTRODUCTION}

Since the beginning of the production of TATB PBX there has been a large degree of variability in the physical properties of the pressed material, It became apparent very early that much of the variability in physical properties could be attributed to $P B X$ processing or manufacturing techniques. The first parameter found to significantiy affect physical properties was the granule size of the molding powder. This was determined by viewing the manner in which the physical test specimens broke. In the case of the LLL B4, which had large granules, breakage was along the PBX granule boundaries. An in-depth discussion of granule size effects has been given previously(1). It will not be addressed in this series of processing experiments because the formulation process has been adjusted to produce small uniform granules. Other variables including concentration. TATB particle size and processing time were evaluated this quarter.

\section{DISCUSSION}

\section{LARGE SCALE PBX PRODUCTION}

The following lots of TATB PBX were formulated:

$$
\begin{aligned}
& \text { RX-03-AB - 90\% TATB/10\% Kel-F } 800 \\
& \text { Lot No. } 5184-133-02 \\
& \text { Lot No. } 5227-133-01 \\
& \text { Lot No. } 5268-133-01 \\
& \text { RX-03-BB - } 92.5 \% \text { TATB } / 7.5 \% \text { Kel-F } 800 \\
& \text { Lot No. } 5218-145-01 \\
& \text { RX-03-AU - 95\% TATB } / 5 \% \text { Kel-F } 800 \\
& \text { Lot No. 5246-141-01. }
\end{aligned}
$$

The RX-03-BB and the RX-03-AU were made from the $309 \mathrm{~kg}$. TATB powder blend, No, 5175-135-01, LLL B7, blended in the Day Nauta Mini-Mixer last quarter.

(1).H. D. Johnson, A. G. Osborn, T. L. Stallings, "TATB PBX Formulation," MHSMP-75-5M, October - December 1974. 
The compression and tensile strength curves of PBX made with LLL B7 are given in Figs. 1 and 2, respectively. Also included for comparison are results from previous lots. The overall trend for each successive lot of PBX to have improved properties is clearly shown. The reason for this will be discussed and illustrated in the next section of this report (Processing Parameter Study). All the physical properties data presented are summarized in Table I.

\section{PROCESSING PARAMETER STUDY}

The purpose of this series of experimental studies is to more precisely identify the major contributing factors affecting physical strength. Those factors suspected of affecting physical properties have been included for examination.

For practical considerations this study was conducted predominately in the 30-1itre reactor. Unless otherwise stated, the processing parameters and materials conditions were as follows:

Vessel - 30-1itre reactor

TATB - LLL B6 Lot 5123-135-01

Kel-F 800 - Lot 552 - precipitated from acetone

Batch Size - $1.8 \mathrm{~kg}-96 \mathrm{~g}$ of HE per litre of water

Processing Time $-1 \mathrm{hr}$

Pressing Size - $3.4 \mathrm{~kg}$

Test conditions for physical properties specimens were:

Compression $-0.001 \mathrm{~mm} / \mathrm{sec}$ constant crosshead speed

Tensile $-0.002 \mathrm{~mm} / \mathrm{sec}$ constant crosshead speed

A constant pressing size of $3.4 \mathrm{~kg}$ was chosen because of variations in physical properties observed between specimens made from small 2-7 kg pressings and larger $100 \mathrm{~kg}$ pressings. Pressed density is not reported here becausc generally density has not been a problem; it has been on the order of $1.900 \mathrm{Mg} / \mathrm{ml}^{3}$.

The basic slurry procedure is to strip the solvent in the kettle until small hard granules are formed. The granules are not pulled "green" (with much solvent remaining). This is the same procedure used in the past for producing large quantities of PBX.

\section{BATCH CONCENTRATION}

Physical strength data for the batch concentration experiments are shown in Figs. 3 and 4 . Maximum stress and strain at complete failure are shown as functions of batch concentration in Fig. 5. Results obtained from material made in the 300-gallon kettle are also included for comparison. Fig. 6 shows examples of specimen breakage. Notice that the largest batch, $7.3 \mathrm{~kg}$, with the poor strength failed at the granule interface although the granules are smal1. Batch concentrations of 100 
to 140 grams TATB per littre of water produced near optimum physical properties.

\section{PROCESSING TIME}

The effects of processing time are shown in Figs. 7 and 8 and summarized: in Fig. 9. Previous work indicated that the length of time the PBX was in the kettle affected physical properties, i.e., the longer the batch remained in the kettle after the stripping of the solvent began, the poorer the properties. Therefore, this series was run for 1 hour to 3 hours. The compression data show a loss in strain at 3 hours, however, the tensile data do not show a clear différence. "It is concluded from these results that a processing time of 1.5 to 2 hours is satisfactory.

\section{COMPARISON OF KEL-F LOTS}

The effects of Kel-F purity are given in Figs. 10 and 11. The precipitated $\mathrm{Kel}-\mathrm{F}$ 800. was dissolved in acetone and precipitated into water prior to being made into a lacquer. Removal of the emulsifier by this technique aided in obtaining the exact composition but did not result in improved physical properties compared with Kel-F as received from the manufacturer. This indicates that there is no real physical property advantage in the use of precipitated Kel-F 800.

\section{TATB MANUFACTURER AND PARTICLE SIZES}

There appears to be variations in particle size distribution between manufacturers of TATB al though this series is incomplete and additional work is necessary before firm conclusions can be drawn. The physical strength curves for formulation batches made from various lots of. TATB are shown in Figs. 12 and 13 and the TATB particle size distributions are shown in Figs : 14 and 15. These data are currently being subjected to statistical-correlation in order to evaluate possible relationships. Physical properties do appear to be a function of the TATB source and particle size distribution.

\section{EVALUATION OF CORDOVA LLL B7}

Blend 7 of RX-03-BB as shown in Figs. 1 and 2 gave excellent mechanical properties. Sub-batches and a 30-1itre batch are compared in Figs. 16 and 17. Data obtained in the 30-1itre reactor on the LLL B7 are very similar to those produced in the larger 300-gallon kettle. The data from the sub-batches are similar to that from the blend. 


\section{MISCELLANEOUS}

A formulation with $10 \% \mathrm{Kel}-\mathrm{F}$ has higher tensile and compression strain than the $7.5 \% \mathrm{Kel}-\mathrm{F}$ batches. Data are presented in Figs. 18 and 19. Other variables investigated which appeared not to affect physical strength were (1) treating the TATB crystals with a surface active agent, the polysaccharide MRL 22A, prior to making the TATB into PBX, (2) the use of a non-porous TATB crystal which was synthesized by a water amination process, and (3) the use of acid washed TATB.

\section{CONCLUSIONS}

The latest large PBX blend, LLL B7, gives superior mechanical properties to previous blends. As a result of the past and present processing experiments, it is concluded that next to PBX granule size, the batch concentration, i.e., the ratio of $\mathrm{HE}$ to water, has the strongest influence on physical strength. Now that some of the factors affecting physical strength have been identified and it is possible to reproducibly make "good" lots of TATB PBX of any size, experimental studies and statistical correlations will be made to understand how these factors influence strength. 
Table I. TATB Physical Properties

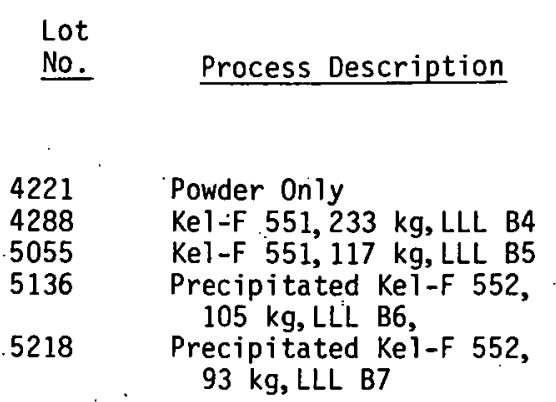

$5196-03 \quad 1.8 \mathrm{~kg} / 96 \mathrm{~g} / \mathrm{e}^{a}$

$5190-03 \quad 2.7 \mathrm{~kg} / 132 \mathrm{~g} / \mathrm{e}$

$5196-04 \quad 3.6 \mathrm{~kg} / 180 \mathrm{~g} / \mathrm{e}$

$5192 \quad 5.4 \mathrm{~kg} / 276 \mathrm{~g} / \mathrm{\ell}$

$5191 \quad 7.3 \mathrm{~kg} / 360 \mathrm{~g} / \mathrm{\ell}$

$\begin{array}{ll}5176-03 & 1.0 \mathrm{hr}^{b} \\ 5196-03 & 1.5 \mathrm{hr}^{a} \\ 5197-03 & 2.0 \mathrm{hr} \\ 5205-03 & 3.0 \mathrm{hr}\end{array}$

$\begin{array}{ll}5206-05 & 552 \text { Plain } \\ 5176-03 & 552 \text { Purified } \\ 5210-03 & 553 \text { Purified } \\ 5210-06 & 554 \text { Purified }\end{array}$

\begin{tabular}{|c|c|c|c|c|}
\hline \multicolumn{2}{|l|}{$\mathrm{Con}$} & \multirow{2}{*}{$\begin{array}{c}\text { Work To } \\
\text { Rupture }\left(\mathrm{kJ} / \mathrm{m}^{3}\right)\end{array}$} & \multicolumn{2}{|c|}{ Tension } \\
\hline $\begin{array}{l}\text { Stress } \\
(\mathrm{MPa})\end{array}$ & $\begin{array}{c}\text { Strain } \\
(\%)\end{array}$ & & $\begin{array}{l}\text { Stress } \\
\text { (MPa) }\end{array}$ & $\begin{array}{c}\text { Strain } \\
(\%)\end{array}$ \\
\hline
\end{tabular}

RX-03-BB BLENDS

$\begin{array}{cccccc}19.51 & 1.8 & 277.7 & 1.5 & 4.41 & 0.06 \\ \star & \star & \star & 3.4 & 5.51 & 0.09 \\ 17.05 & 4.73 & 699.7 & 9.7 & 7.31 & 0.22 \\ 14.13 & 5.82 & 718.5 & 18.1 & 10.70 & 0.26 \\ 20.45 & 5.81 & 1007.4 & 19.2 & 9.71 & 0.28\end{array}$

BATCH CONCENTRATION

$\begin{array}{lllrrr}18.38 & 6.2 & 978.8 & 12.9 & 8.45 & 0.26 \\ 18.24 & 5.8 & 923.6 & 18.2 & 8.76 & 0.32 \\ 18.13 & 4.9 & 726.4 & 9.6 & 7.38 & 0.18 \\ 18.61 & 1.9 & 270.4 & 11.3 & 7.94 & 0.25 \\ 17.40 & 2.0 & 269.8 & 7.5 & 7.05 & 0.19\end{array}$

PROCESSING TIME

$\begin{array}{rrrrrr}16.70 & 7.0 & 996.1 & 12.3 & 7.78 & 0.25 \\ 18.30 & 6.2 & 1009.1 & 14.4 & 8.45 & 0.26 \\ 16.97 & 7.6 & 1102.9 & 18.5 & 8.73 & 0.33 \\ 18.60 & 5.2 & 863.9 & 15.1 & 8.73 & 0.29\end{array}$

COMPARISON OF KEL-F

$\begin{array}{rrrrrr}17.91 & 7.1 & 1064.3 & 17.4 & 8.07 & 0.30 \\ 16.70 & 7.0 & 996.1 & 12.3 & 7.78 & 0.25 \\ 17.73 & 7.6 & 1102.3 & 11.7 & 8.40 & 0.22 \\ 17.04 & 6.5 & 923.4 & 11.9 & 7.94 & 0.23\end{array}$

TATB MANUFACTURERS AND PARTICLE SIZE

$\begin{array}{llrlrrrr}5212-03 & \text { Cordova Coarse. (Lot 004) } & 18.95 & 6.4 & 1184.0 & 3.1 & .7 .43 & 0.07 \\ 5232-06 & \text { PX Coarse- (5178-16-02) } & 16.38 & 7.0 & 971.0 & 10.4 & 7.00 & 0.23 \\ 5213-03 & \text { Cordova Bimoda (Lot 007) } & 21.58 & 4.8 & 324.8 & 13.9 & 9.51 & 0.22 \\ 5226-06 & \text { PX BiModal (5174-16-02) } & 17.26 & 6.6 & 974.1 & 13.4 & 7.79 & 0.26 \\ 5213-06 & \text { Cordova Fine (Lot 003) } & 20.14 & 4.5 & 791.4 & 20.4 & 9.61 & 0.31 \\ 5226-03 & \text { PX Fine (4128-16-01) } & 18.51 & 7.5 & 1188.0 & 11.0 & 7.97 & 0.20\end{array}$

CORDOVA LLL B7

$\begin{array}{llllllll}5216-03 & \text { 30-Litre Reactor (1.8 kg) } & 22.32 & 5.5 & 1018.7 & 18.6 & 10.40 & 0.30 \\ 5209 & 300-G a l \text { Sub-Batch 132 g/2 } & 1.9 .79 & 7.5 & 1309.6 & 19.0 & 9.88 & 0.33 \\ 5206 & 300-G a 1 \text { Sub-Batch 132 g/l } & 19.63 & 6.2 & 1036.7 & 21.9 & 9.76 & 0.32 \\ 5218 & \text { Blend 7 } & 19.93 & 6.0 & 1004.4 & 19.6 & 9.77 & 0.28\end{array}$

\section{MISCELLANEOUS}

\begin{tabular}{|c|c|c|c|c|c|c|c|}
\hline $\begin{array}{l}5176-03 \\
5211-03 \\
5216-06 \\
5211 \\
5233-03\end{array}$ & $\begin{array}{l}\text { Control } b \\
\text { TATB/MRL 22A } \\
\text { Water-Aminated TATB } \\
10 \% \text { Kel-F } 800 \\
\text { Acid Washed TATB }\end{array}$ & $\begin{array}{l}16.70 \\
17.81 \\
18.21 \\
16.38 \\
17.27\end{array}$ & $\begin{array}{l}7.0 \\
7.6 \\
6.2 \\
8.6 . \\
6.2\end{array}$ & $\begin{array}{r}996.1 \\
1120.7 \\
1004.1 \\
1174.5 \\
955.6\end{array}$ & $\begin{array}{l}12.3 \\
10.8 \\
11.4 \\
23.3 \\
13.6\end{array}$ & $\begin{array}{l}7.78 \\
8.02 \\
7.85 \\
8.23 \\
7.60\end{array}$ & $\begin{array}{l}0.25 \\
0.20 \\
0.22 \\
0.40 \\
0.27\end{array}$ \\
\hline
\end{tabular}

*io data avaizable - used citifierent method

$a_{\text {Same batch }}$

$b_{\text {Same batch - Control }}$

NOTE: Unless othemise stater! conditions were: 30-litre reactor. LLL B6 TATB. purified Ke $\mathrm{LF}$ Lot $5.52: 1.8 \mathrm{~kg}(\mathrm{~A} \mathrm{Zb}$ ) batch size. $1 \mathrm{hr}$ processins time. $96 \mathrm{~g} H E /$ litre water $\left(0.8 \mathrm{lb} \mathrm{HE} / \mathrm{gal}\right.$ water), $\because . k_{i}(7.5 \mathrm{ib})$ pressing. 


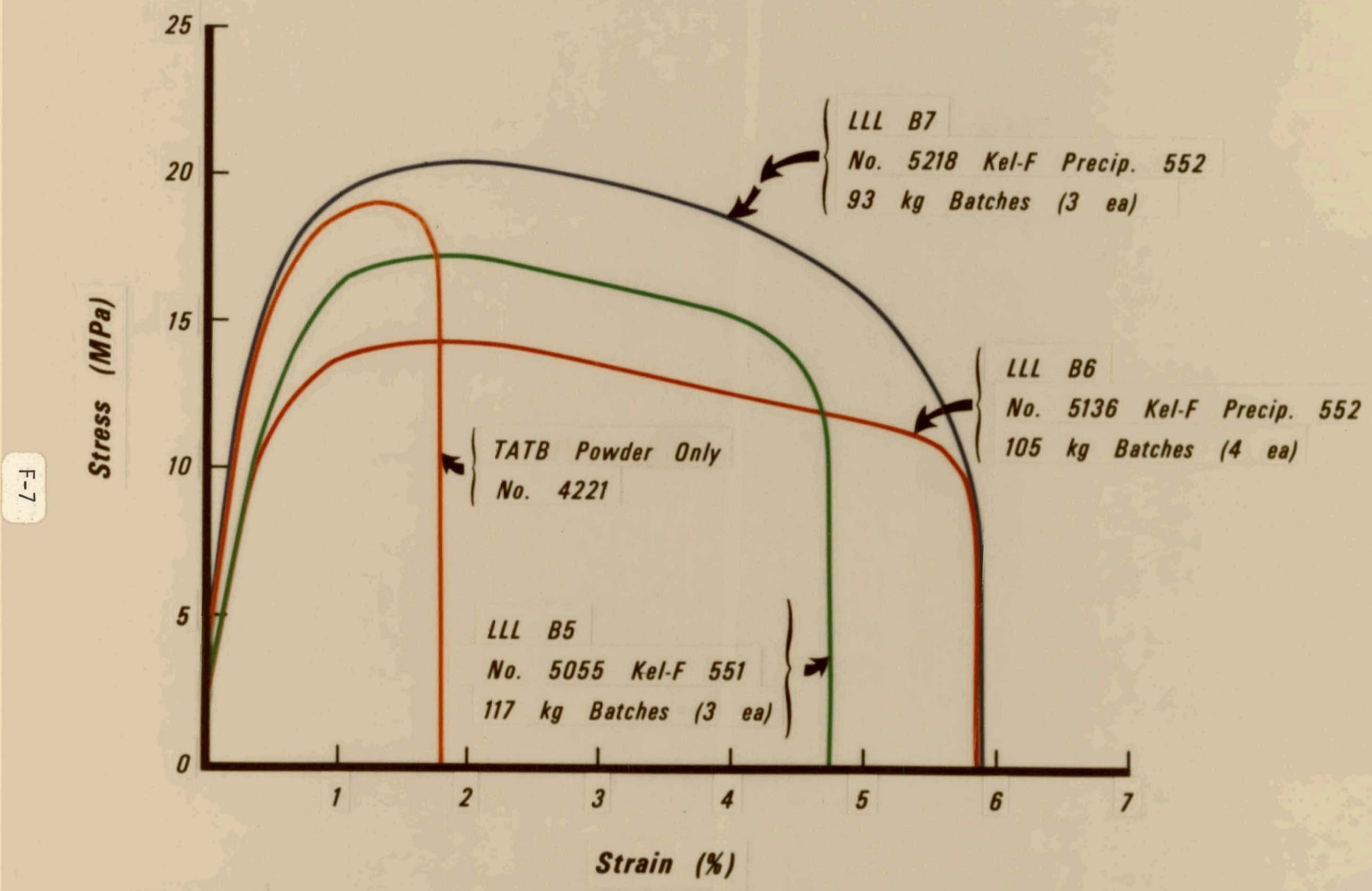

Fig. 1

RX-03-BB 7.5\% KEL-F 800 COMPRESSII N TESTS 


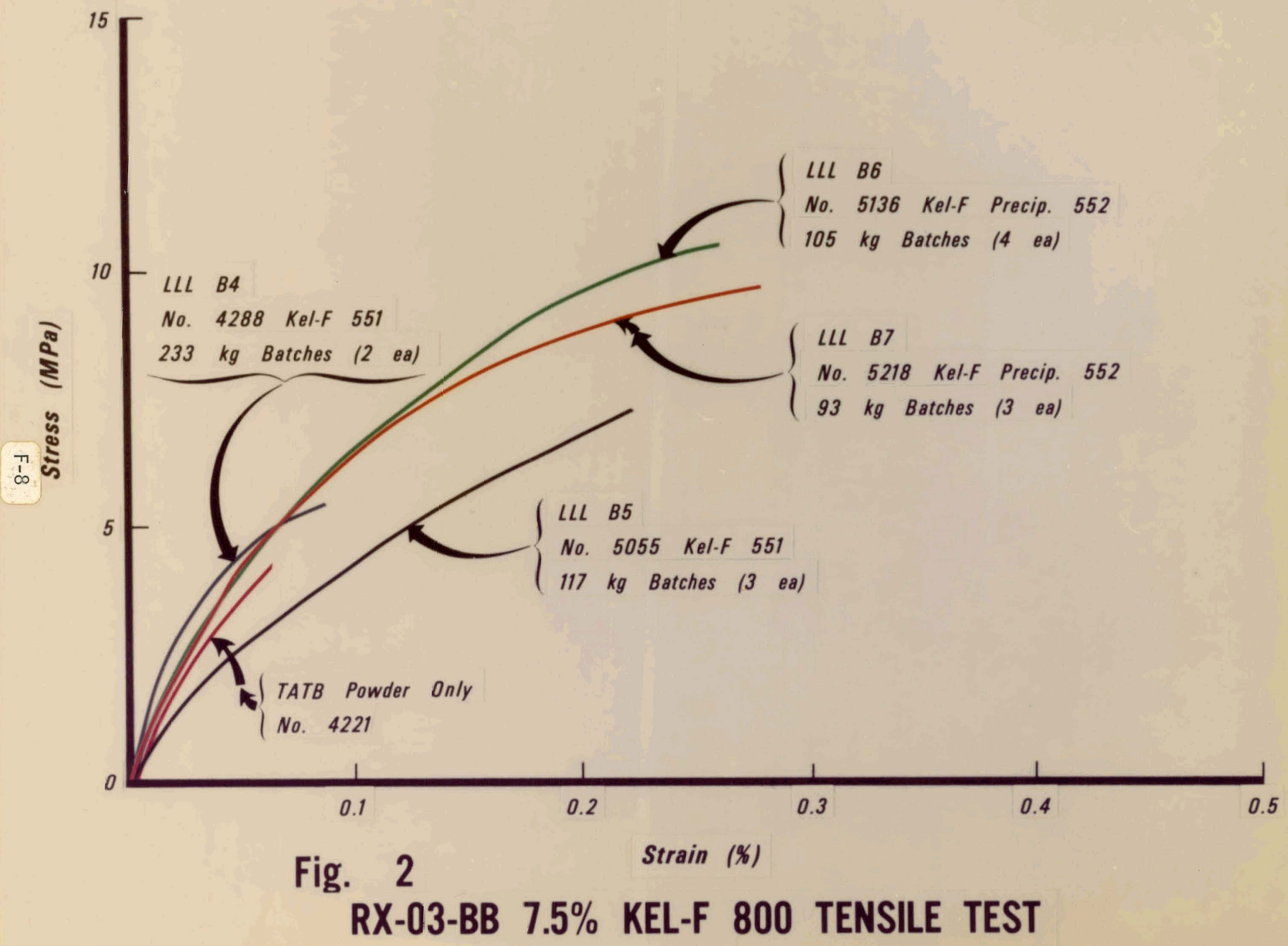




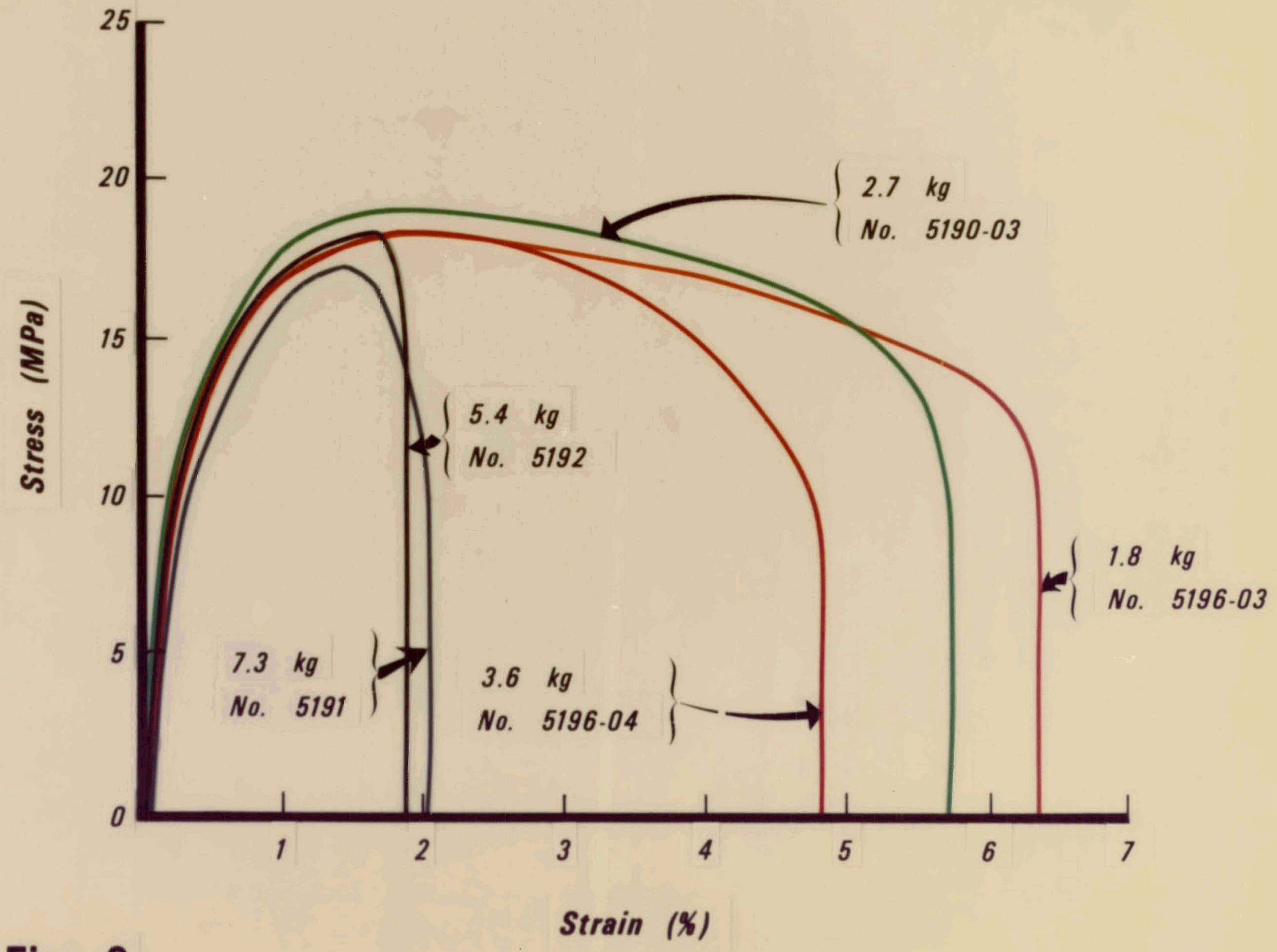

Fig. 3 RX-03-BB BATCH CONCENTRATION COMPRESSION TESTS 


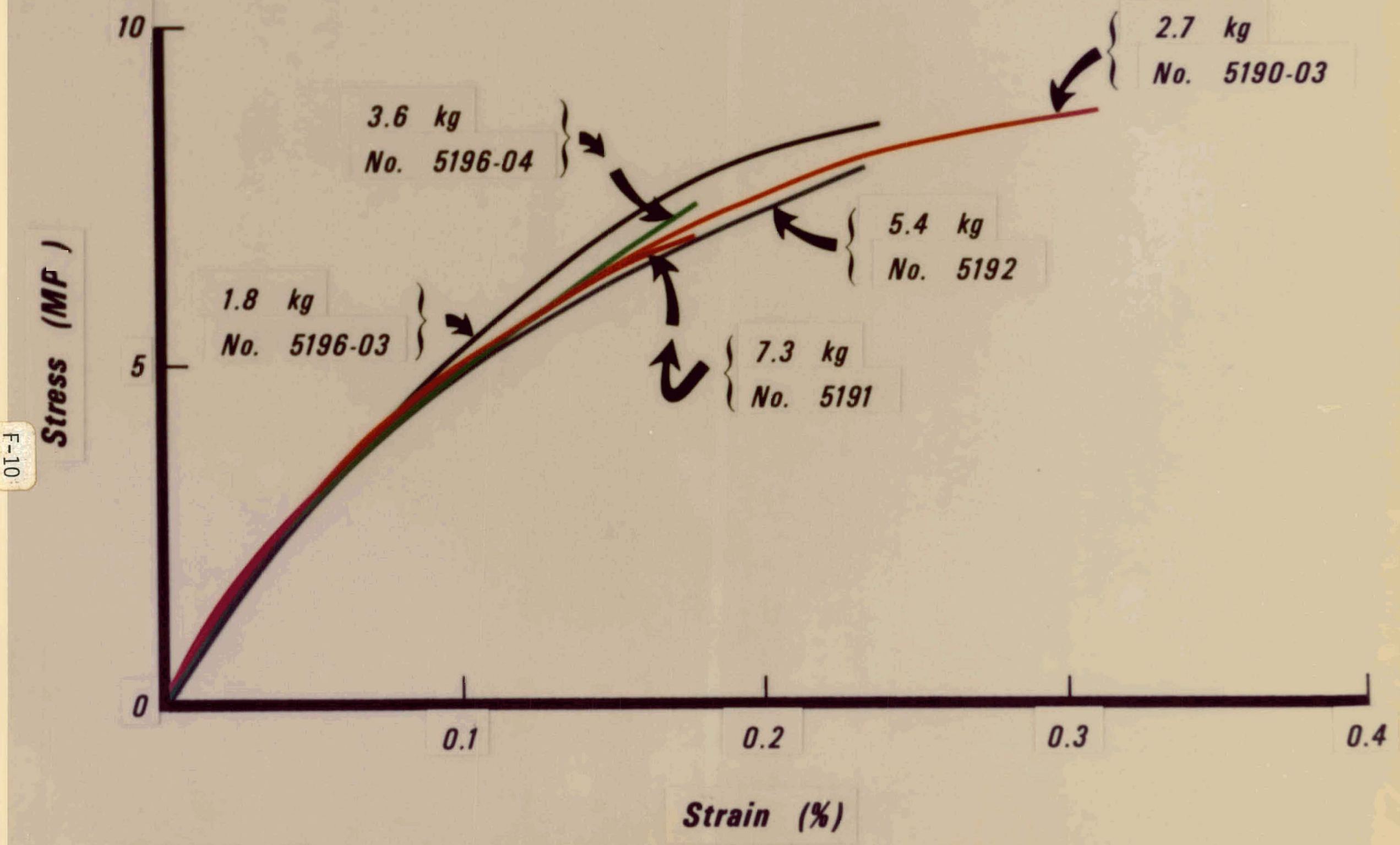

Fig. 4 


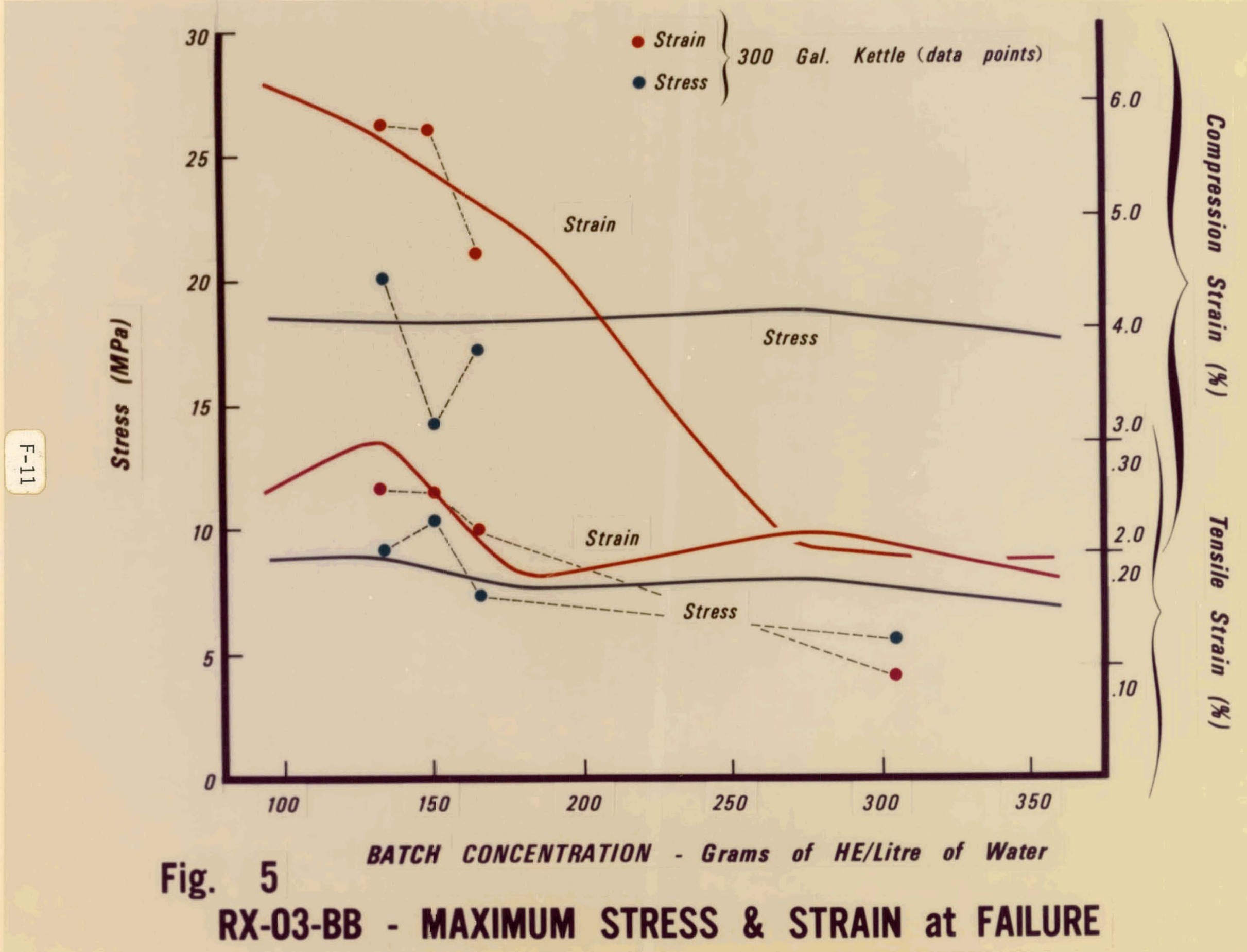




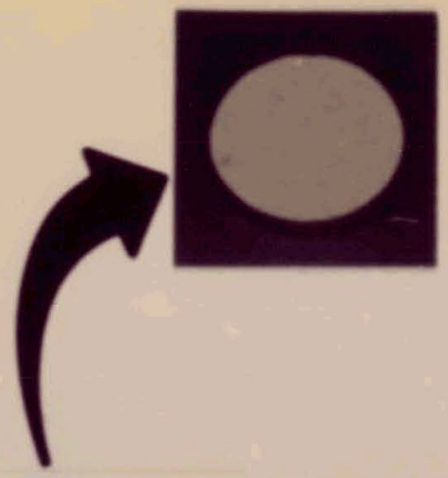

No. 5190.03

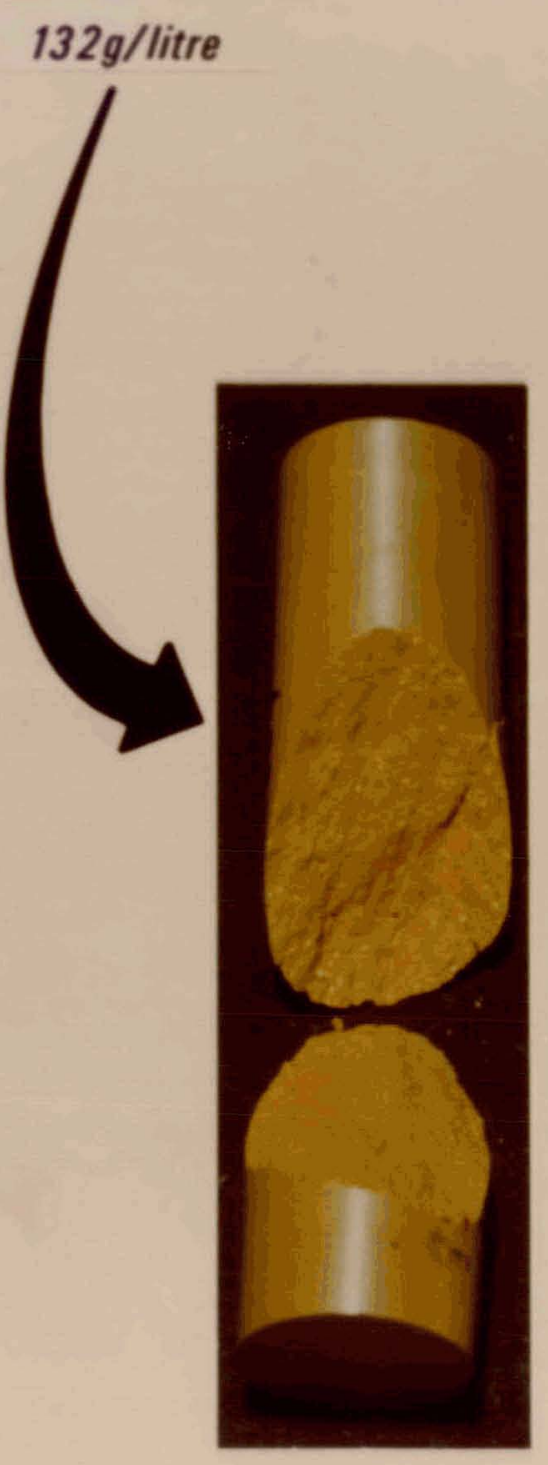

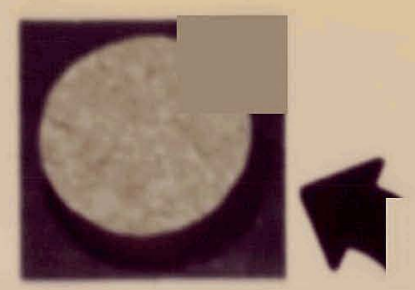

Tensile Specimen

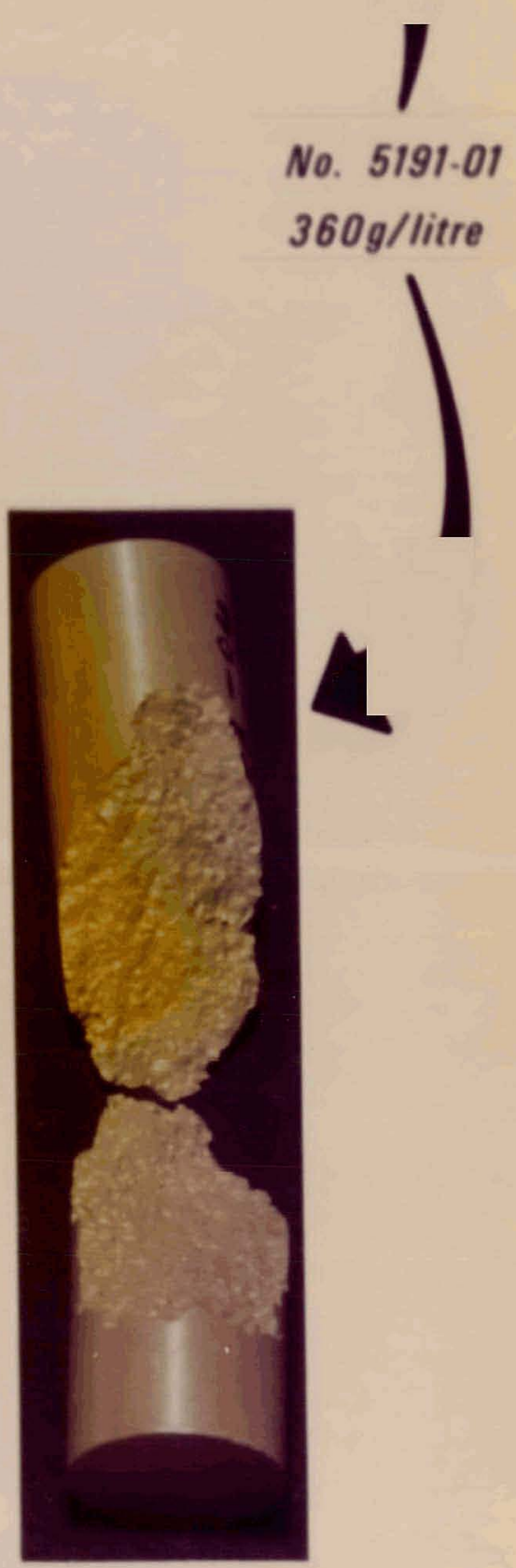

Compression Specimen

Fig. 6

Broken Test Specimen 


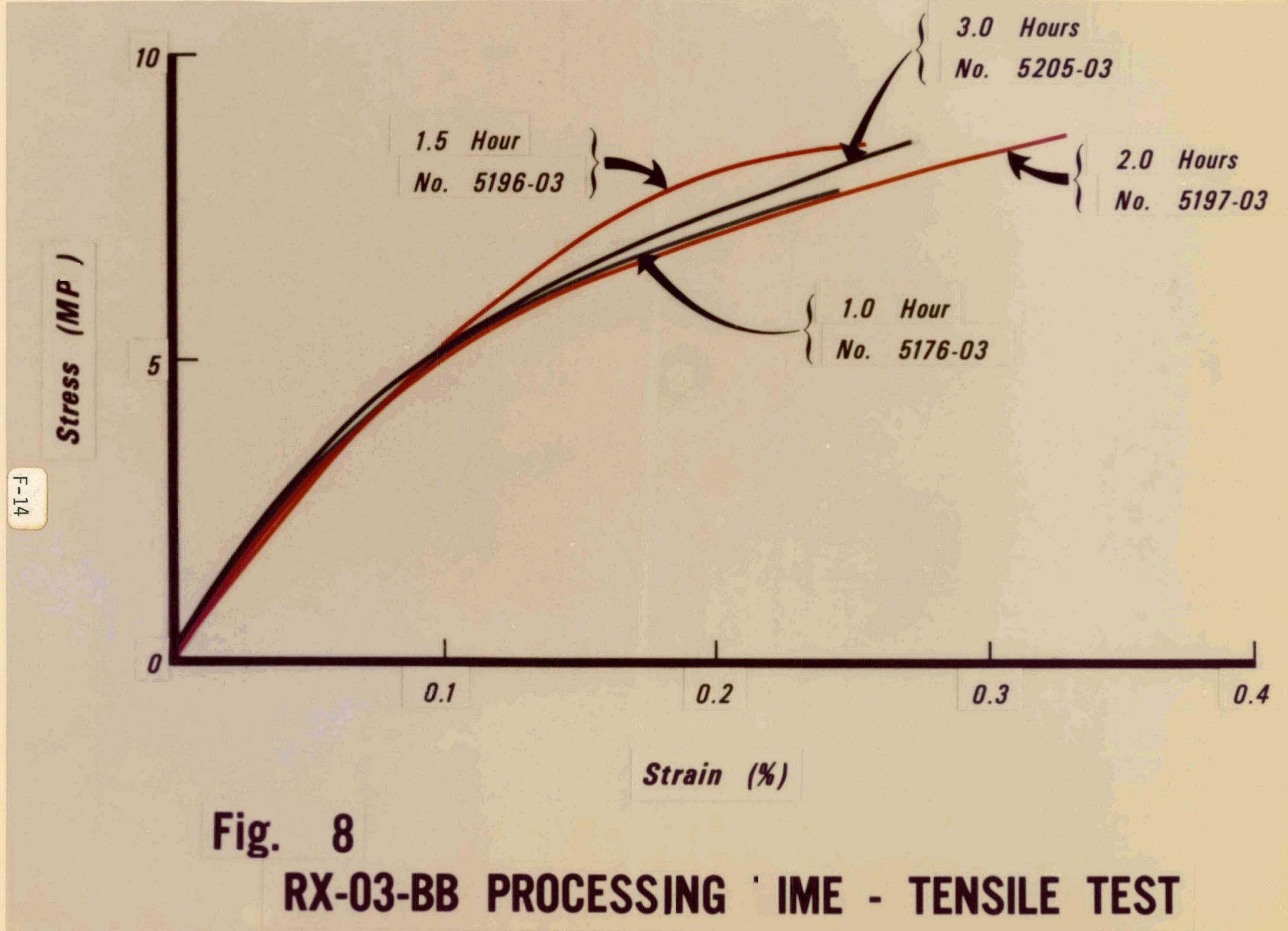




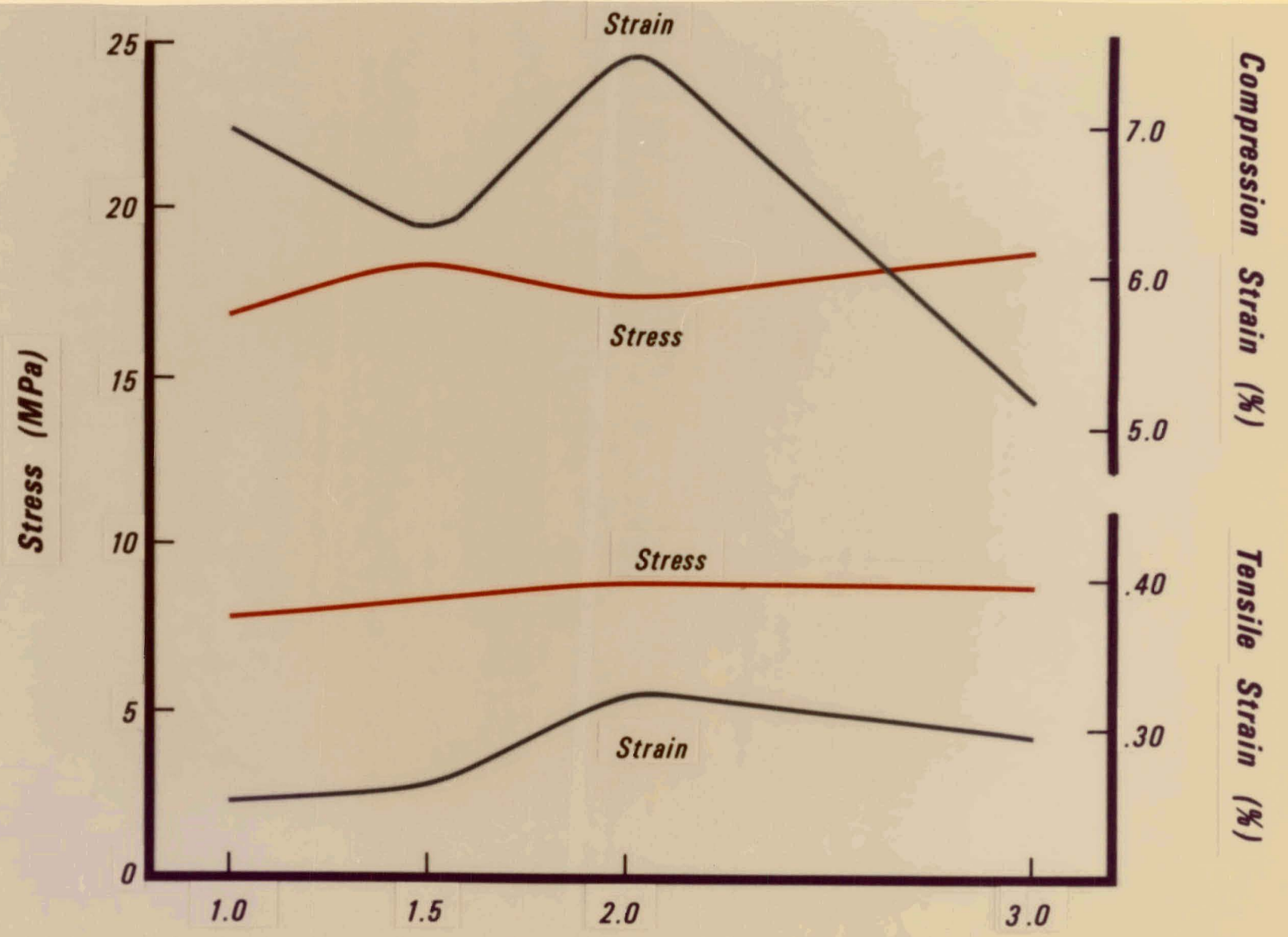

Fig. 9

PROCESS TIME, (Hours)

RX-03-BB - MAXIM M STRESS \& STRAIN at FAILURE 


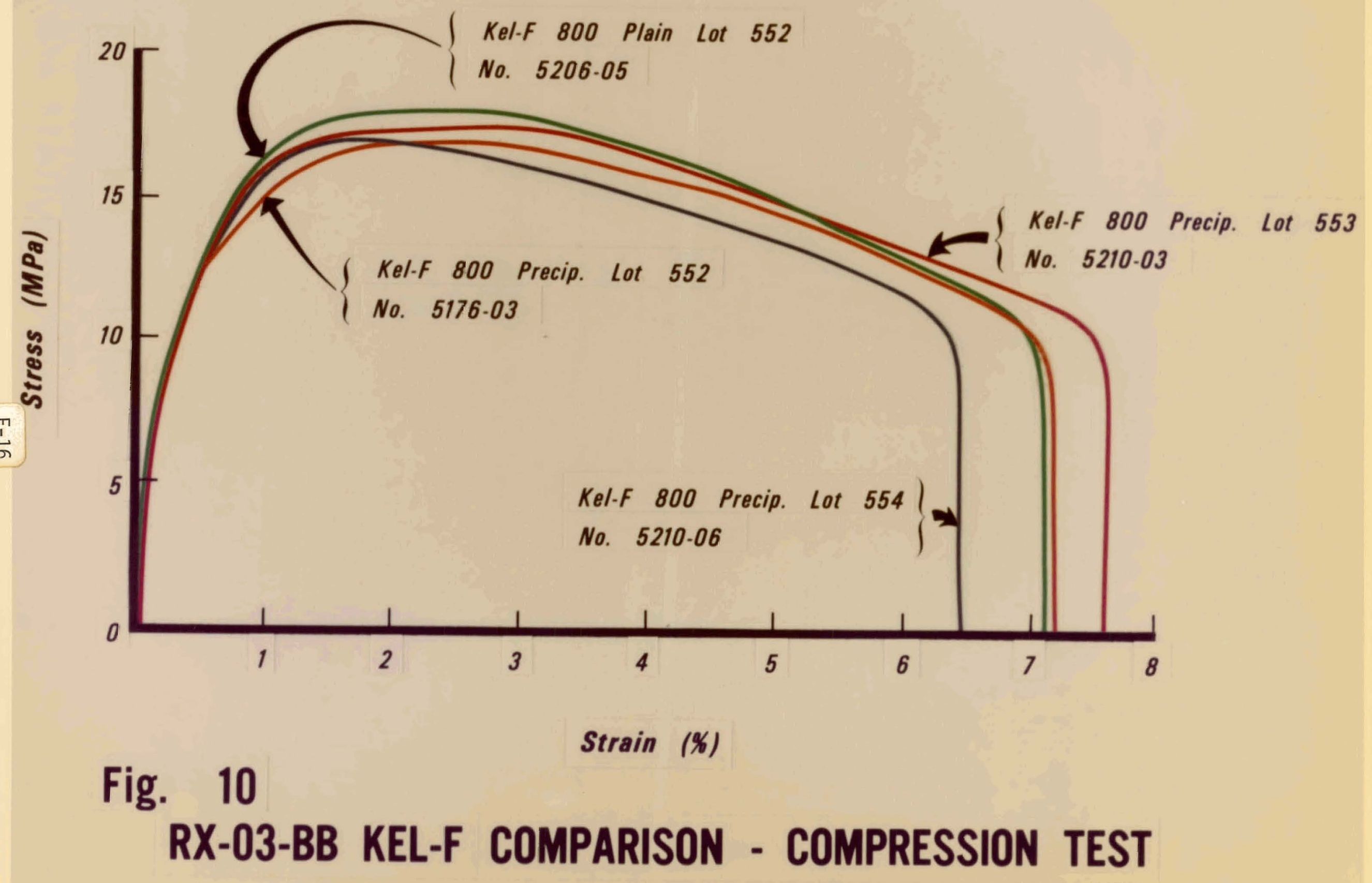




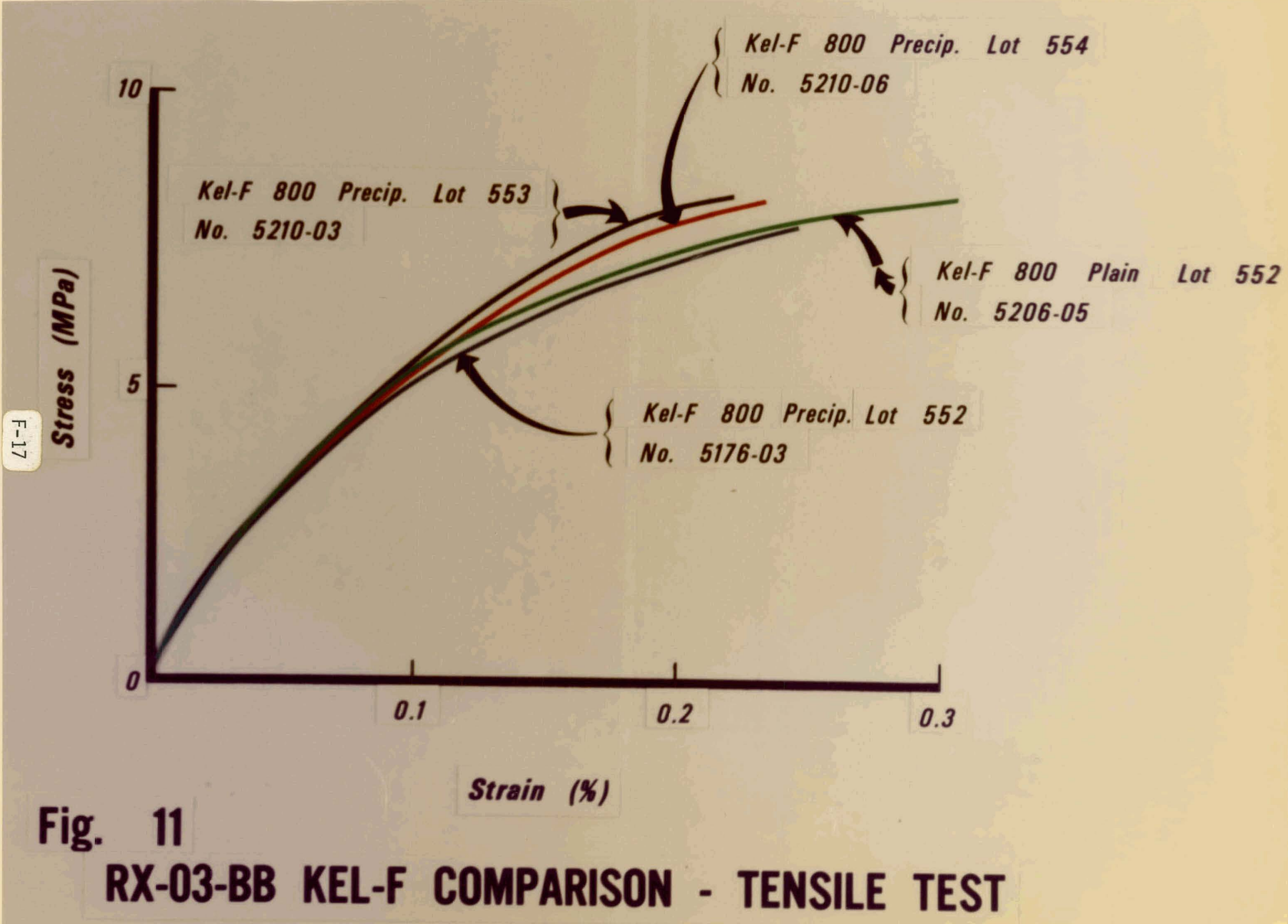




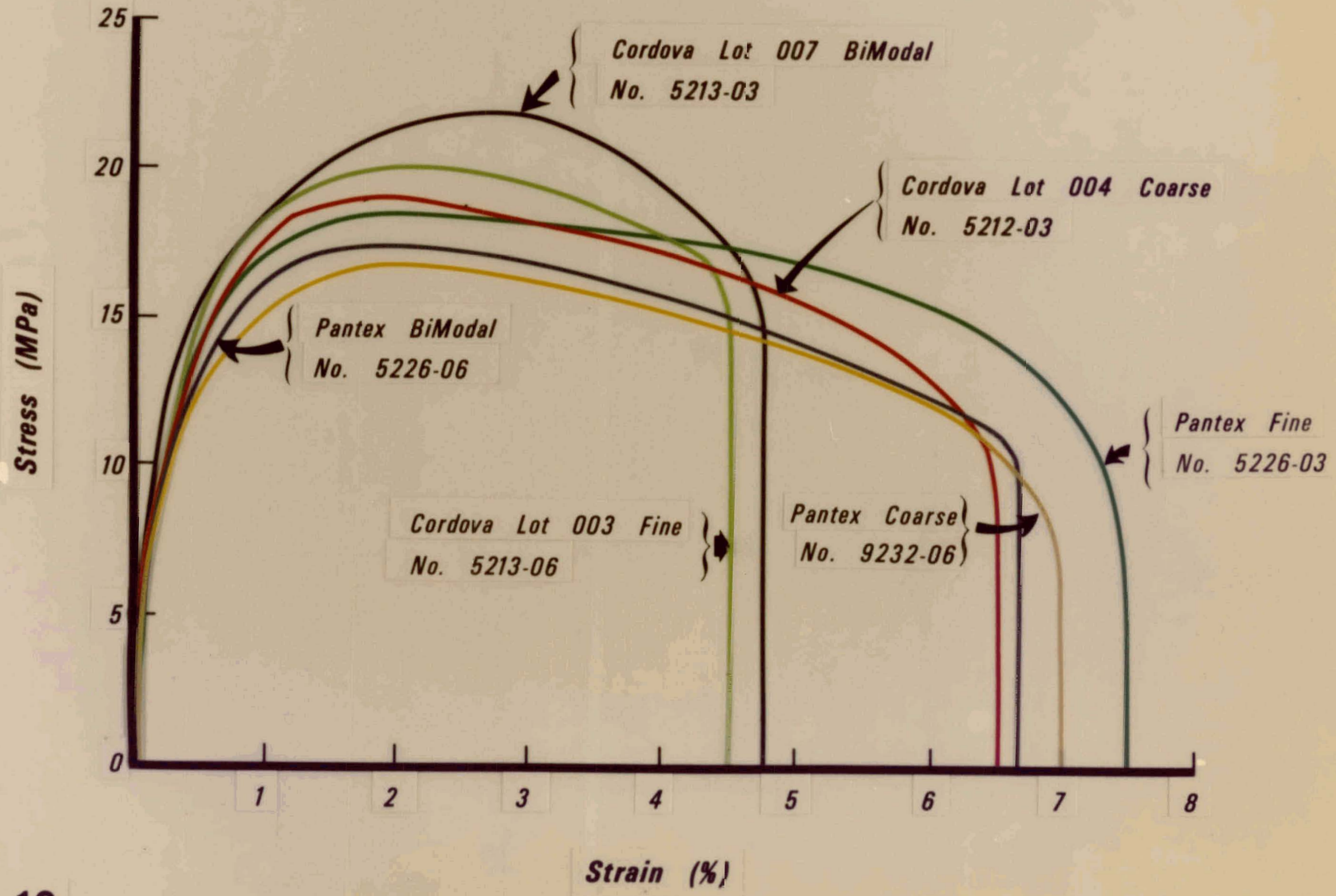

Fig. 12 RX-03-BB TA 'B MANUFACTURERS PARTICLE SIZE COMPRESSION TEST 


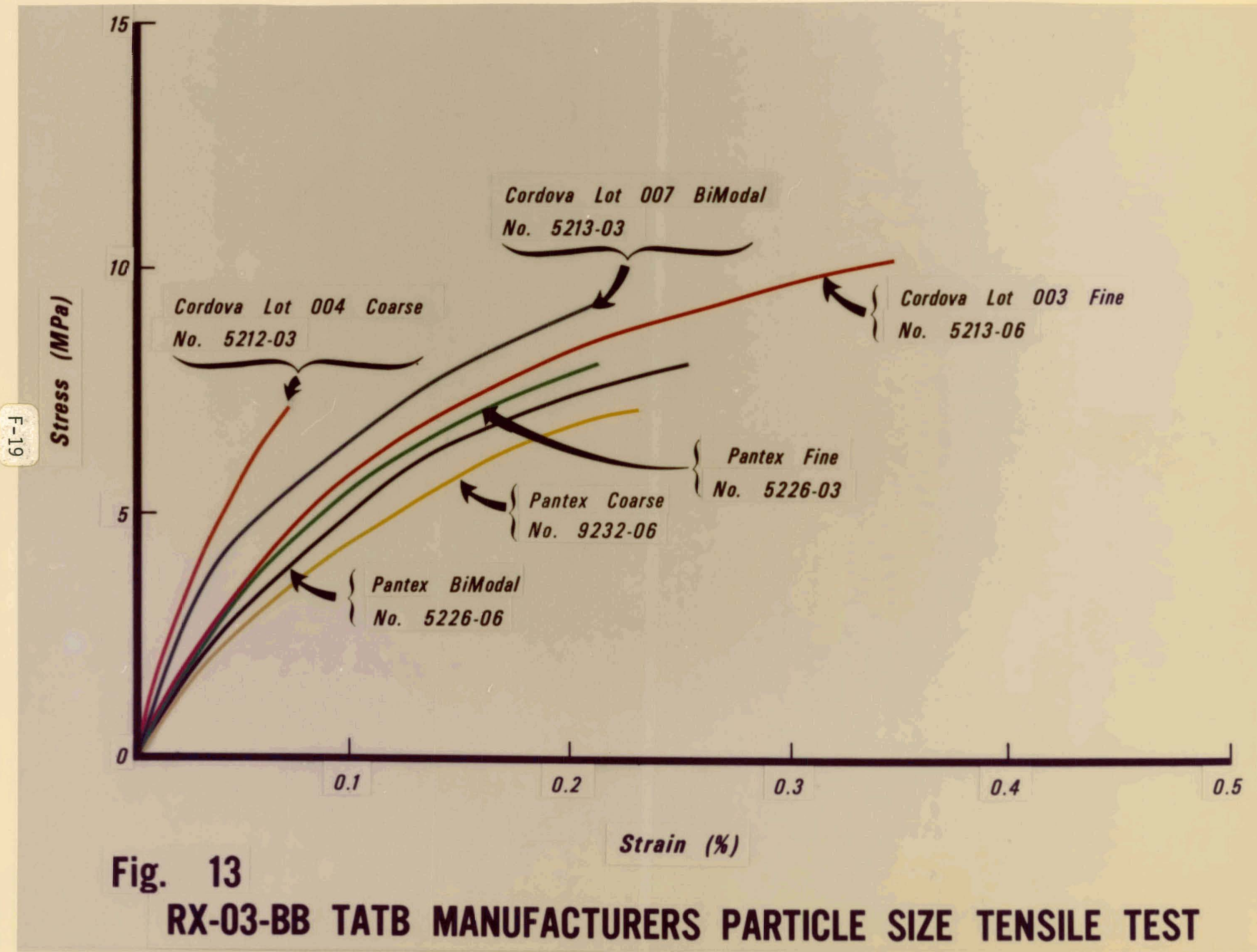




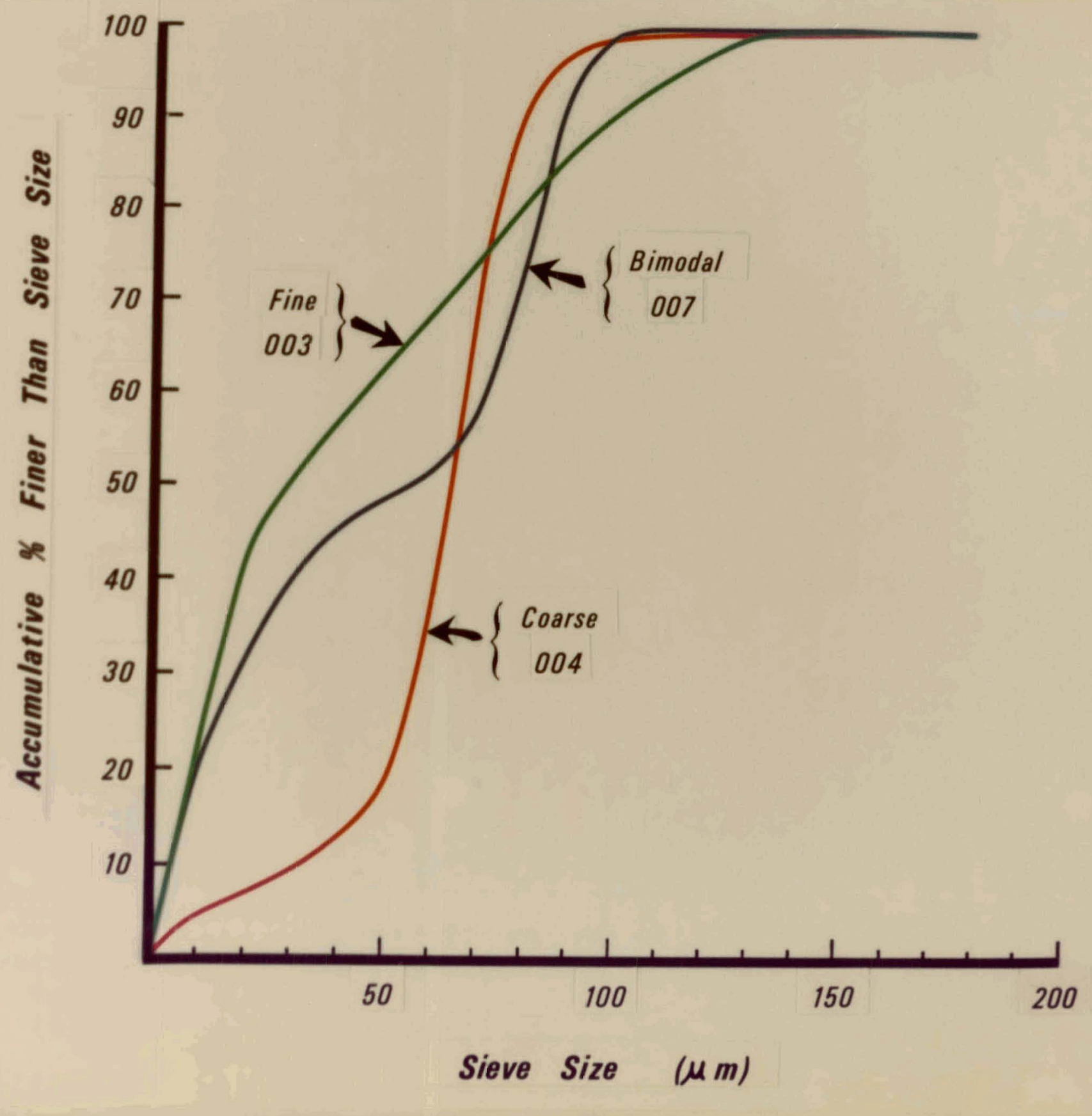

Fig. 14

Sieve Analysis of Cordova Chemical Co. Synthesized TATB 


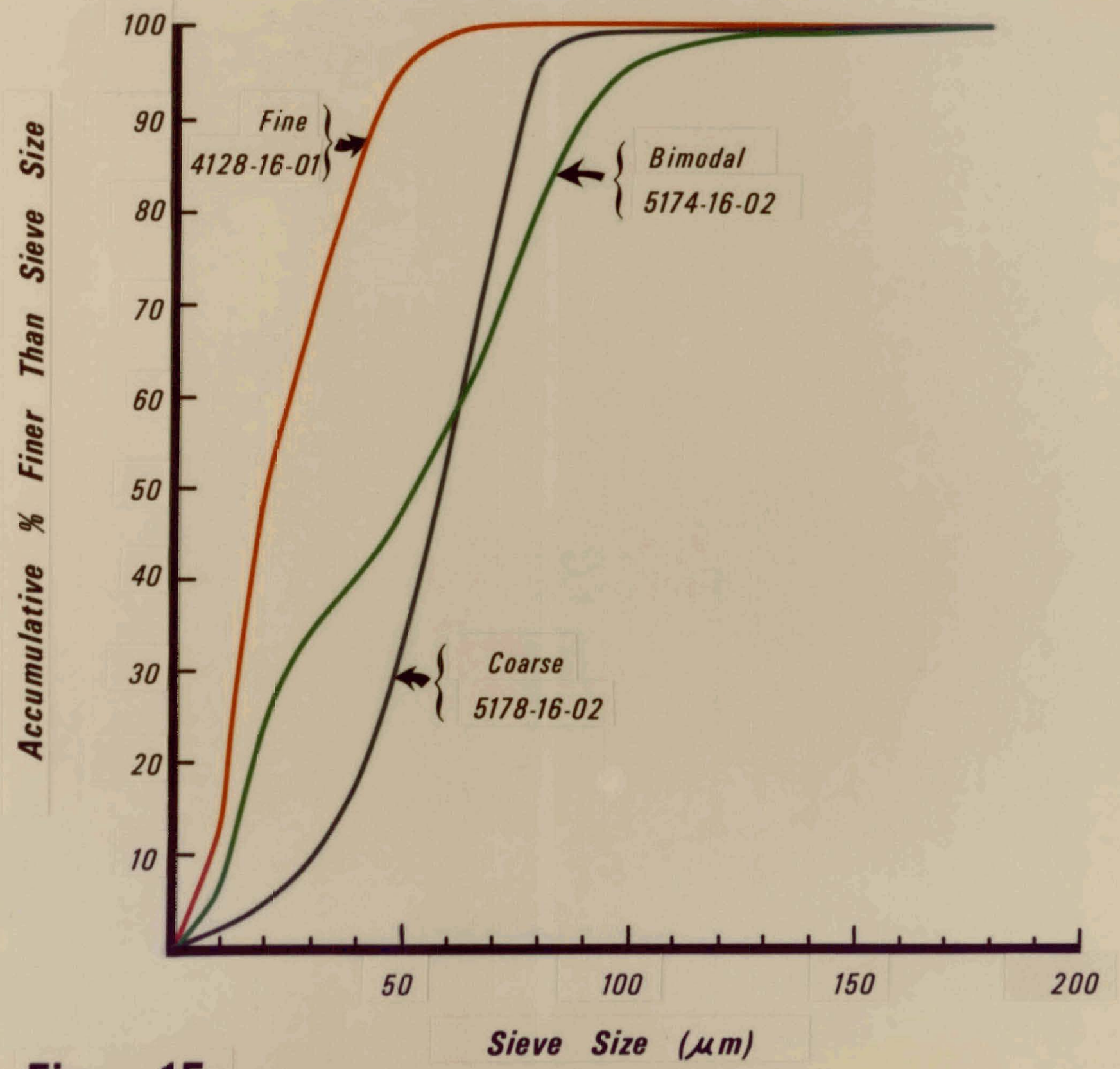

Fig. 15

Sieve Analysis of Pantex Synthesized TATB 


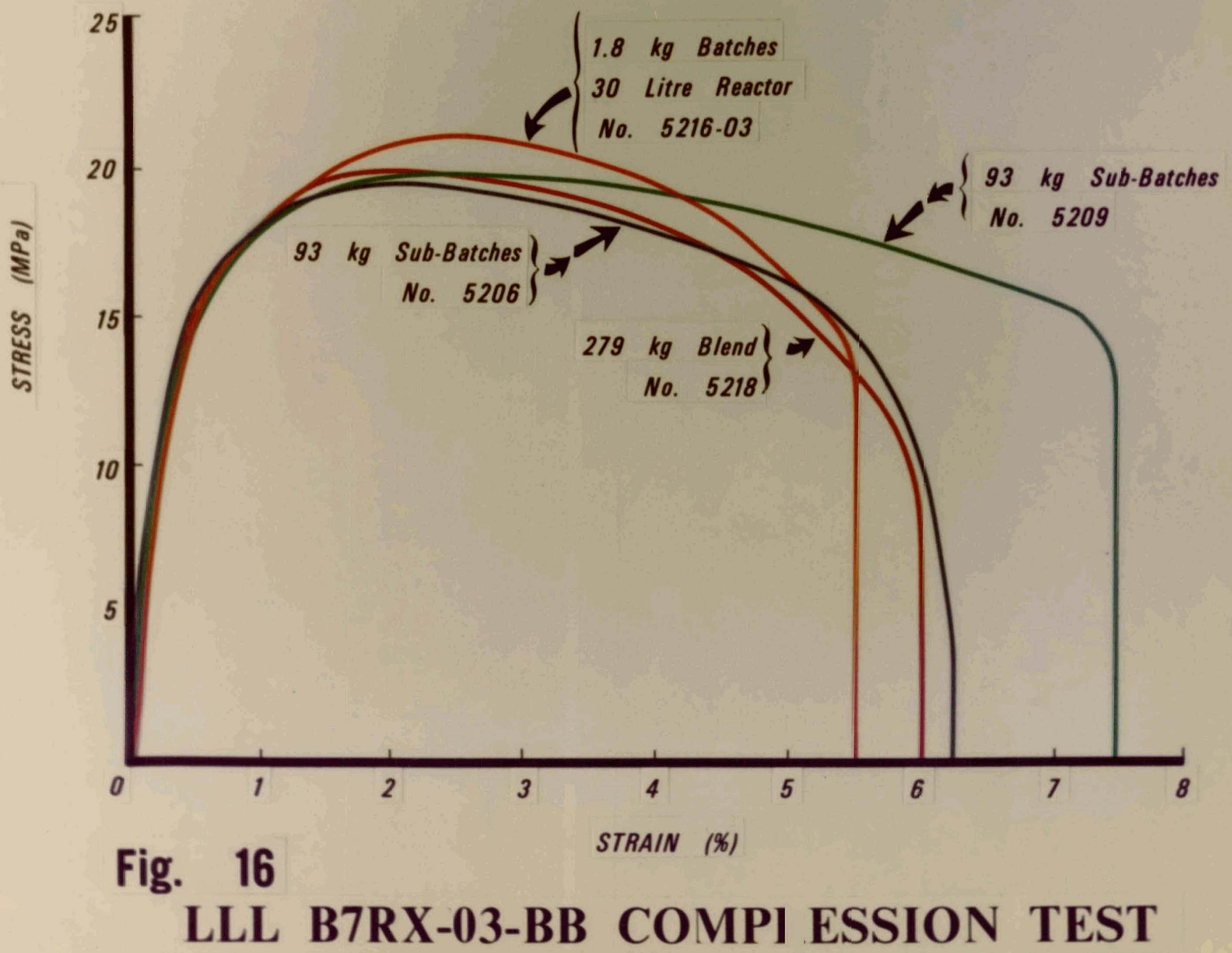




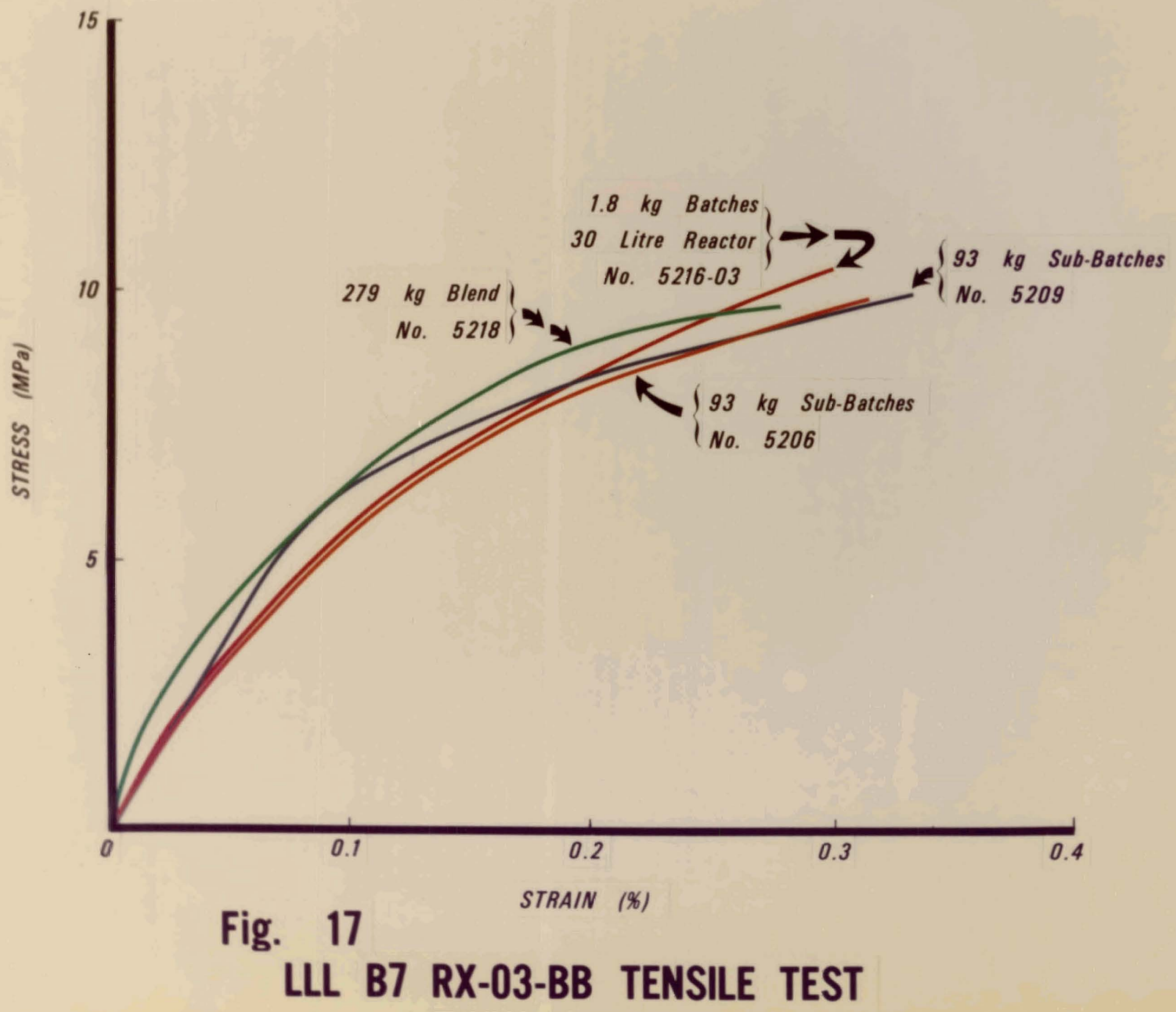




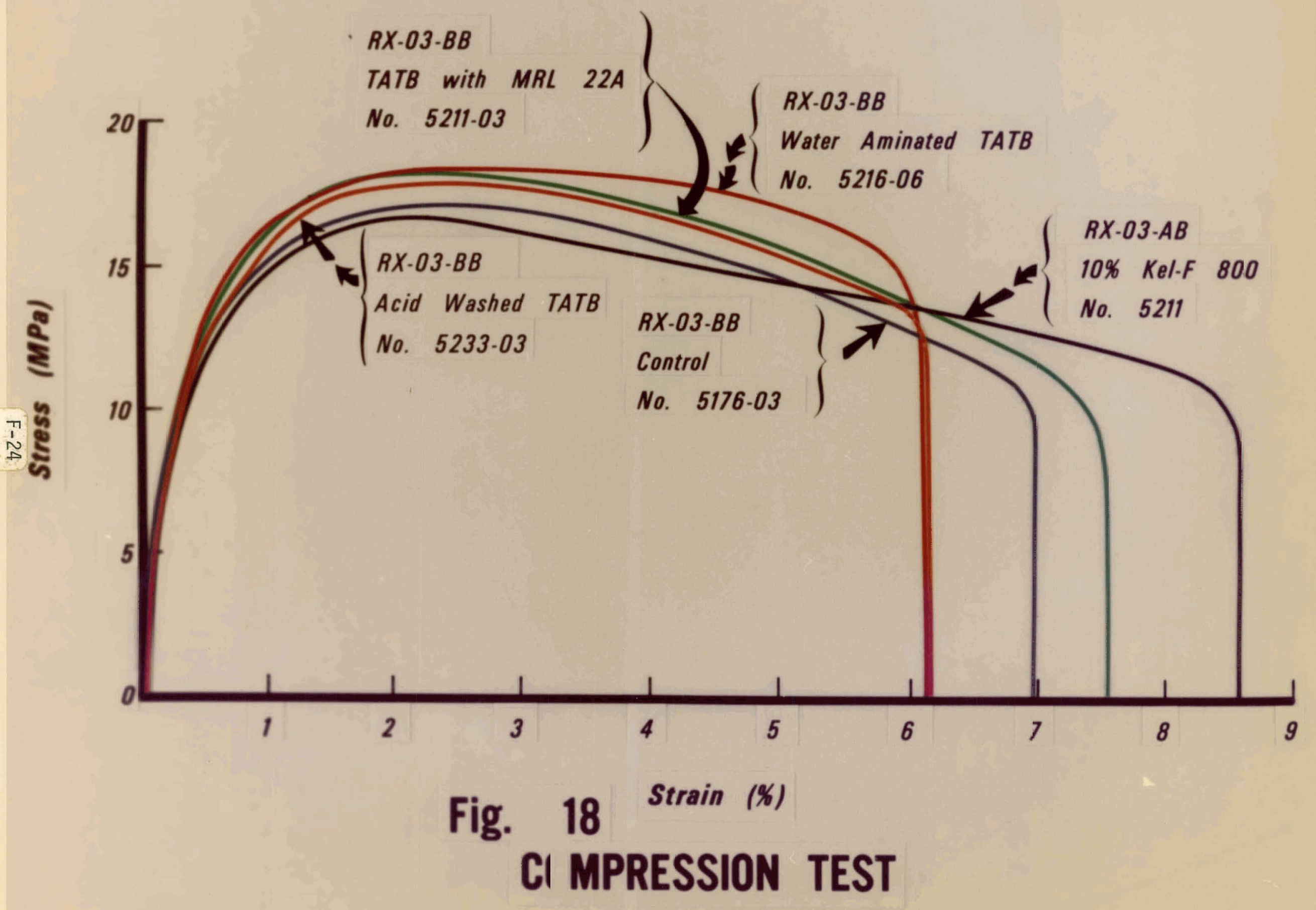




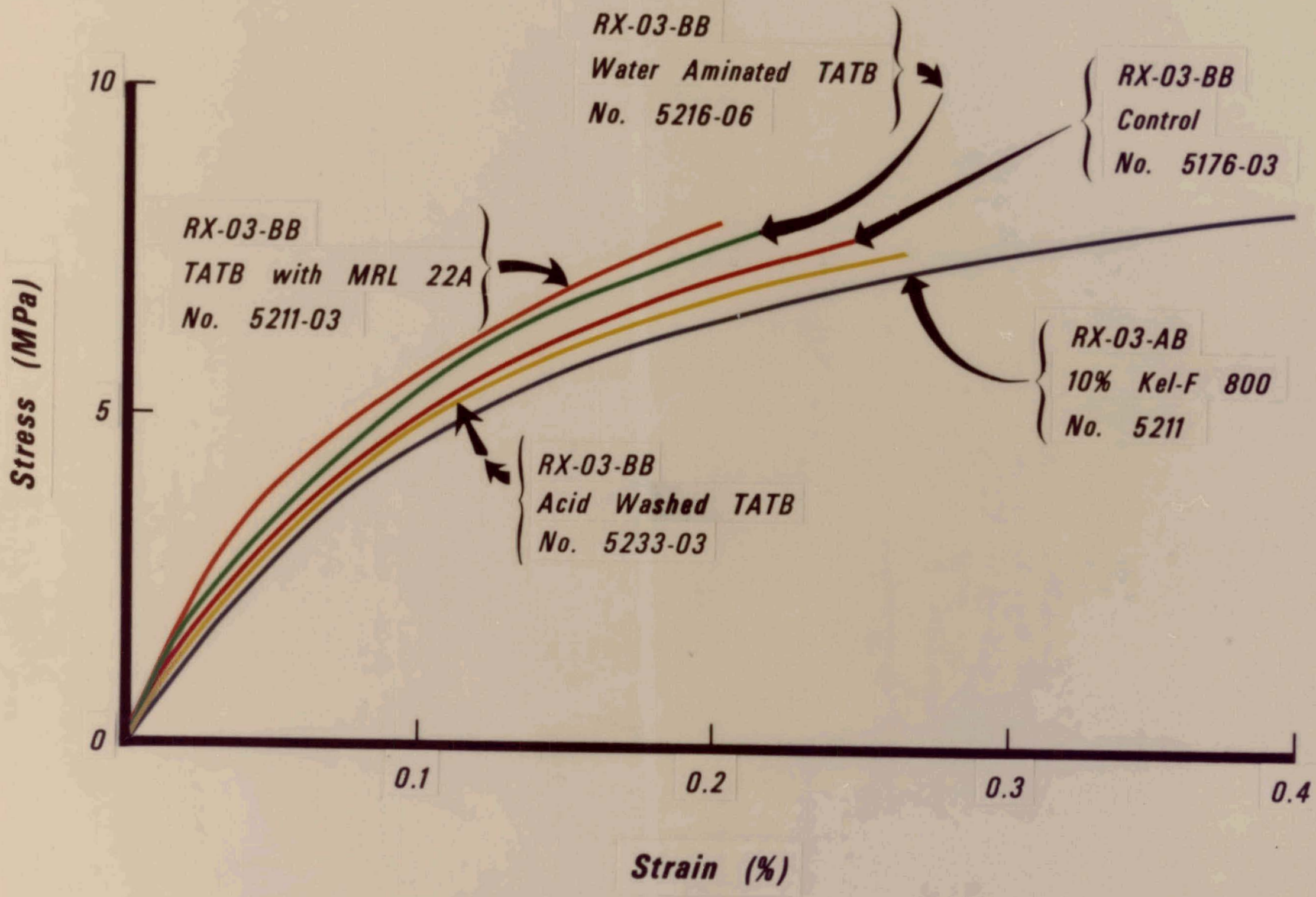

Fig. 19

TENSILE TESTS 